\title{
The Portraiture of Aging: A Psycho-Analytic Study of A Man Called Ove by Fredrik Backman
}

\author{
Aathira A. S and A. Poongodi \\ Department of English and Foreign Languages, SRM Institute of Science \\ and Technology, Kattankulathur, India
}

\section{ABSTRACT}

Human life, at all its stages, is worthy of representation in literature. The paper focuses on the process of aging, its loneliness and nostalgia, through the psychological exploration of the novel, A Man Called Ove by Fredrick Backman. The novel narrates the life and past of a fifty-nine year old man, Ove, through a non-linear narrative. His hard-core exterior and staunch principles make him intimidating in his neighborhood. However, as the story unveils, a peep at his childhood and youth helps in the understanding of the inner realms of Ove's character and furthermore, the effects of complexities of aging in the emotional and psychological health of the person. This is a critical analysis of the novel, A Man Called Ove with cross references to the gerontological theory, Second Generational Socio-emotional Selectivity Theory by Susan T Charles and Joanna Hong. It is a psycho-analytic exploration of Ove, the protagonist, through the life-stage of aging, its social and mental aspects.

KEY WORDS: GERONTOLOGY, PSYCHOANALYSIS, COGNITIVE CONTROL HYPOTHESIS, POSITIVITY EFFECT, STRENGTH AND VULNERABILITY INTEGRATION.

\section{INTRODUCTION}

"No, that is the great fallacy: The wisdom of old men. They do not grow wise. They grow careful."-A Farewell to Arms by Ernest Hemingway Hemingway's quote lights up one of the most important tendencies of old people when it comes to the process of aging. The process itself, sometimes compels them to shrink to their memories and into themselves. The quietness can signify peace or untold misery in every case. Literature has always been the space for representation of the wonderful and the arduous phases of life. It has reflected the characteristics of every age of life, the innocence and trauma of childhood, the insecurities and earnestness of teenage, the pains and pleasures of youth followed by the stillness and agitation of old age too./ The paper is a psycho analytic study on the novel, A Man Called Ove written by the Swedish

Biosc Biotech Res Comm P-ISSN: 0974-6455 E-ISSN: 2321-4007

\section{crossef}

Identifiers and Pagination

Year: 2021 Vol: 14 No (8) Special Issue

Pages: 146-149

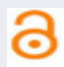

creative
This is an open access article under Creative
Commons License Attribn 4.0 Intl (CC-BY).
DOI: http://dx.doi.org/10.21786/bbrc/14.8.33

Commons License Attribn 4.0 Intl (CC-BY).
DOI: $h t t p: / / d x . d o i . o r g / 10.21786 / b b r c / 14.8 .33$ writer, Fredrik Backman and translated to English by Henning Koch.

The novel explores the themes of aging, its characteristics, challenges and responsibilities, also, Ove's take on the process of aging and echoes his life story and the happy and distressing memories on this phase of life. The analysis is drawn with cross references to the socioemotional selectivity theory, particularly the concept of Strength and Vulnerability Integration, by Susan T Charles and Joanna Hong.

Robert Frost says, "The afternoon knows what the morning never suspected." This is a reflection on the general inclination of the people to not recognise the aging process. Sometimes they find themselves in a position where they're utterly clueless on the mental, emotional, physical transition that is happening. Physical deficiencies have medicines as remedies in most cases but the effect of the incapacity on the mental state is neglected or overlooked, most of the times. However, this has a lasting effect on the psyche of the person. A Man Called Ove, written by the Swedish columnist, blogger and writer, Fredrik Backman, was published in English in the year 2014. It was one of the best sellers during the
Article Information

Received: 06 ${ }^{\text {th }}$ June 2021

Accepted after revision: $19^{\text {th }}$ July 2021 
time recounting a story of happiness, trauma, memories and moreover, the little but significant things of life. Backman has framed the whole story around a man of principles, called by the name of Ove.

The narrative revolves around the transition of the character from a quiet teenager to an insecure youth and to an intimidating old man of the neighborhood. The phase of aging with its physical and emotional vulnerability combined with the strengths in personality and character has been represented through the plotline. Growing old, specifically, growing old alone after the death of the partner, as a tiring and despairing stage in life is depicted through the events in the novel and Ove's take on life. Though his perspectives and stances are the windows through which every other character is portrayed, many lives have been painted into the picture of the novel. Ove is fifty nine and lives in a locality all by himself after the death of his beloved wife, Sonja. He lost Sonja to cancer but is still not attuned to the fact that she is no more. Her memories and timely responses keep replaying in his head, echoing around the empty house except for him and the cat. At a particular point, he decides to suicide, no longer able to bear the pain of loss, but is brought back to normal by the disruptive intervention of the newly moved-in family next door. Ove, then, juggles his life through the comical arguments of the husband and pregnant wife, tantrums of their two small children and the social issues of a few other youngsters.

A man of principles, unwilling to bend according to the turn of the world, Ove manages to gain a grip over his life through these events and embraces death in a far meaningful and peaceful manner at the end. The novel is analysed with cross references to the concept of Gerontology and in turn, the theoretical aspects of Strength and Vulnerability Integration in the older generation. According to the Institute of Gerontology, College of Public Health, University of Georgia, Gerontology is the study of aging in older adults. Susan T Charles and Joanna Hong have conceptualized Second Generational Socio-emotional Selectivity theory that relates aging and the significance of emotional goals. The process of aging on adults brings about a variation in the emotional capability of each individual. They are found to be more at peace when they are in pursuance of emotional goals. One of the recent developments in the socio-emotional selectivity theories is Strength and Vulnerability Integration (SAVI). SAVI focuses on the capability of aging adults to achieve emotional goals and the hindrances to sustain emotional well-being.

A Man Called Ove narrates the story of an aging man, resilient to the changes of the society around him and adamant in the adherence to his principles. His difficulty in recouping to the loss of his only friend in life, his wife plagues every activity that he engages in. this pain-induced frustration earns him a lot of enemies in the neighborhood. Eventually, he boards up his emotions and tries to fight with everything happening around him. However, the emotional goals he is thrust with during the course of the story sustains him and gives him the purpose he longs for, since Sonja's death. 'Every man needs to know what he is fighting for'. (Backman). These lines by Sonja keeps him moving forward through all the responsibilities and challenges that he is faced with. During the old age, it is indeed the notion of a goal that acts as a stimulant to move on further. Ove speaks for the community of aging adults faced with the reality of forgetfulness, slow comprehensibility and in want of peace and quiet. Emotions are the drive and experiencing the little pleasures of life are what they crave for.

The Strangest Superhero: Sonja said once that to understand men like Ove and Rune, one had to understand from the very beginning that they were men caught in the wrong time. Men who required a few simple things from life, she said. A roof over their heads, a quiet street, the right make of a car, and a woman to be faithful to. A job where you had a proper function. A house where things broke at regular intervals, so you always had something to tinker with. (Backman, A Man Called Ove) Ove is introduced in the first few lines of the novel as a person with a short temper and a strict demeanor. He is seen to involve in an argument unnecessarily with a sales boy regarding the purchase of a laptop. On observing the Ove's angry responses, it is seen that, he refuses to acknowledge the fact that he might be unaware of the functioning of certain technological gadgets. Hence the inability to accept the 'growing old phase' has been reflected in his actions.

The Second Generational Socio Emotional Selectivity theory asserts that time is a major factor in the fixation of motivational goals. Motivational goals pave their way to emotional experiences. Cognitive control denotes the ways through which goals or purposes influence human behavior. According to this theory greater level of cognitive control has been exhibited in a person living in positive surroundings than in negative ones. While Ove represents a sturdy man with a hardcore exterior and almost disliked by all of his neighbors, it is very interesting to probe into the cause of positivity in his life. This inbuilt positivity gives way to determination whereby he helps Parvaneh and her kids while their dad falls off a ladder, gives a home to Jimmy and Mirsad, helps Anita protect her husband Rune and so on. The first and foremost reason is Sonja, his wife and the only source of happiness that he possessed in life. Her death plunges Ove into a pit of depression with which he struggles all his life. Though once thrust with an opportunity to help or offer service to someone in need, he never restrains. The emotional goal quests that he involved himself in were the everyday events of the people in his locality. Towards the end, it is evident that this obligation is the life source for Ove. 'The director says you are just like your father.'

Ove didn't turn around. But his back was straighter as he walked off. (Backman, A Man Called Ove) His father had been another source of inspiration and optimism in Ove's life. His father never verbally taught him anything. It is by close observation that he learned the 
actions that defined a man. Even at the stake of losing a job, Ove did not waver once from the word that he had given his father. The positivity effect as described in the theory posits that emotional information over rides nonemotional information in the brains of the older adults. Here, it is seen that the pictures that Parvaneh's (the pregnant neighbor next door) daughters draw and the way they address Ove as their grandfather helps him find meaning in life. He is able to forgive Rune after many years by understanding Anita's plight. The bond they had shared when they were the best of friends influences his memories and decisions about him at present. Social situations and environments rearrange themselves in a way that the positive ones affect the person in a much more significant way than the negative ones.

The strength and vulnerability integration speaks on how emotional experiences get transferred to strengths and negative experiences touch upon the already existing vulnerability both mental and physical in the psyche of a person. Parvaneh, with her noisy and unruly family, Jimmy and Mirsad and their immature decisions in life, Rune and Anita with their unfortunate fate, Sonja with all her love for Ove, gave him all the emotional experiences that made his life purposeful. These form Ove's strength during the phase of growing old. From the verge of suicide, the emotional regulation brought about by these interactions, is what pulls him back. Ove, when he finds himself in unfriendly situations or around insensitive people, it affects his mental stability and ends in the contemplation of suicide. Thus the vulnerability levels are found to be high in old people during unfavorable circumstances. Socio-emotional selectivity theories are used to categorize emotional experiences of individuals. Ove's character and his experiences reflect on the aspects of the strengths and vulnerabilities of the older community while his life is a study on the loneliness of solitude.

'Black And White' With 'Color': She often said that 'all roads lead to something you were always pre-destined to do.' And for her it was, perhaps, it was something. But for Ove it was someone. (Backman, A Man Called Ove) Sonja was the girl he met in the train one day and fell in love and to whom he found it necessary to lie for the first time in his life. She turned his life into a completely new destination with her caress of love for everything that he was, as a person. Her affection for him made him wonder how he was capable of a love so pure and whole in the same lifetime he had been hated by others. Ove believed that Sonja had been the purpose of his life. He followed the path she paved for him and found himself centering all the activities around her. She professed selflessness, love, compassion, knowledge and patience through her actions, all her life. She loved Ove unapologetically and without demanding any change in his habits or behavior.

This is one of the major reasons he was left in crisis once she died. His life lost the grip to which he had held onto all his life. The concept of cognitive control hypothesis is visible in the influence of Sonja on Ove's life. His goal orientation was simply her happiness and everything drove him towards it. He is visibly shattered once the bus accident leads to her abortion. Every time Sonja suffers an emotional crisis, Ove's mental stability is shaken and lower levels of cognitive control is perceived.

The impact of positivity and positive experiences in life causes an emotional regulation in the psyche of older adults. They find themselves far more optimistic, accepting and accommodating of the harsher truths of life. The essential requirement is the presence of a positive spirit in social interactions and activities. He doesn't know what happened to him after her funeral. The days and weeks floated together in such a way and in such utter silence, that he could hardly describe what exactly he was doing. Before Parvaneh and that Patrick reversed into his post box he could barely remember saying a word to another human being since Sonja died. (Backman, A Man Called Ove) These words describe Ove's psychological distress after he is faced with the death of his wife. He even forgets to eat his meal and loses all directions of living. The instability is not perceivable lucidly but is the subtle lining present in all of his angry retorts. The phase of old age along with its emotional constraints and frustrations needs to be accepted gracefully by the individual. A healthy mindset and peaceful demeanor is guaranteed only on this condition which will in turn help them to manage their physical ailments with a positive heart and young spirit.

But Ove loses all of this with the death of Sonja. Her absence is not accepted or acknowledged by him in any manner. He keeps replaying her responses in particular situations over in his head as a defence mechanism to the cruel reality of her death. Unable to grapple with the bereavement of anything that she loved, he still looks after the cat that she loved even if he hates cats. His non-acceptance is punctuated with his memories of her. He has left the house exactly like how it had been after she died so that no change in the surrounding would impose her absence on him. Sonja's departure sets his physical as well as emotional vulnerabilities loose. He is diagnosed with a heart ailment which eventually takes his life in the end. He is struck at the middle of life, left alone to get onto another new phase. Insecurities and doubts suffocate him since there is no vent available. He spends quite a bit of his time in the garage daily. His repetitive monotonous activities leaves him high and dry with no escape from emotional distress. The only instance during which he breaks down is when Anita impresses on him that she needs his help to protect her husband, Rune. That is when the pressure belt is broken and he starts crying. This however has a purgatory effect on his psychological state and he is more humane in his social interactions later on.

Ordinary human behavior transforms itself to a stage where care and attention is primary during old age. The phase requires a delicate concern on the person invoking a purpose or reason for him to continue to live. This is more significant when the individual is left alone and has to continue his life in solitude. Parvaneh and family 
along with Jimmy and Mirsad transfers their purpose in life to Ove's thereby giving him a reason to hold onto. Involvement in activities that excites or provides him with happiness is his way of escape from the pain induced by loss. The only strength in his life had been Sonja and his father. Both of them left him at an earlier stage and he is faced with his fears and vulnerabilities with no one to share. It is to this situation that the neighbors and the journalist barge in. The turning point of life that makes Ove back away from suicide and embrace life again. Thus, his emotional regulations take a turn whereby he dies peacefully, having even seen that coming. His death leaves no one in disgruntlement regarding his attitude or character as everyone sees the essence of the man in the actions he had imposed.

'I don't know. I may have forgotten. You start losing your memory at my age.' (Backman, A Man Called Ove) This is the first sign of acceptance he exhibits in the novel. This shows the decision that he has inwardly arrived at regarding the infirmities of his age. He believed that people needed a function. He always kept himself busy on this belief. Slowly he starts accepting, changing and tuning his mind to accept the fact that he is entering into a different phase. He starts acknowledging that he would feel weak or infirm in health or have a loss of memory. This is the practice that has a positive effect on his psyche when he nears his end.

\section{CONCLUSION}

Literature is one of the ways of escape from the bitter truths and actualities of life. It has been and always will be a form of therapy too, given the chance to ease the pains of living. The world of competition exists with its hassle and a lot is being spoken about the importance of mental health of youth and children and others. In this juncture, it is also important to observe the psychological well-being of the older community. Maybe the fact that they have almost covered a good part of their life is one of the reasons behind the partial negligence. But it should also be noted that it is at this age that they face the most difficult mental challenges like amnesia, dementia, hallucinations and the like. During this phase they require total affection and care which would help them cope with all the challenges alike and lead their lives forward.

"Last scene of all that ends this strange, eventful history,is second childishness and mere oblivion. I am sans teeth, sans eyes, sans taste, sans everything." (Shakespeare) Shakespeare's lines illustrates the idea that anything or anyone nearing the end goes through the childhood again. Everything that happens is a mere repetition of what happened in the past. This signifies that older community requires help and support while they enter into the growing old phase. It is time for them to receive what they have given during the time of need for their children.

\section{REFERENCES}

Backman, Fredrik. Backman, Fredrik. (2014) A Man Called Ove. Manipal: Manipal Technologies Limited, 239.

English T., Carstensen L. (2016) Socioemotional Selectivity Theory. In: Pachana N. (eds) Encyclopedia of Geropsychology. Springer, Singapore. https://doi. org/10.1007/978-981-287-080-3_110-1

Shakespeare, William. (2016) As You Like It. Oxford: Oxford University Press.

Susan T Charles, Joanna Hong. (2016) Second Generation Socioemotional Selectivity Theories." February. Research gate . 25 March 2021 <https:// www.researchgate.net/publication/315548514_Second_ Generation_Socioemotional_Selectivity_Theories>. 